\title{
Errant Kinship, Traveling Song: James Baldwin's Just Above My Head
}

\author{
Jenny M. James Pacific Lutheran University
}

\begin{abstract}
This article considers James Baldwin's last published novel, Just Above My Head (1979), as the culmination of his exploration of kinship, reflecting on the ways distance and loss characterize African-American familial relations. By analyzing Baldwin's representation of Hall Montana's relationship to, and mourning of, his younger brother Arthur, this article argues that $J A M H$ revises the terms of the black family to imagine an alternative, errant kinship that is adoptive, migratory, and sustained through songs of joy and grief. My approach to the novel's portrayal of kinship is indebted to Édouard Glissant's Poetics of Relation (1990), in which he defines "errantry" as a fundamental characteristic of diaspora that resists the claustrophobic, filial violence and territorial dispossession that are slavery's legacies. Baldwin represents errant kinship in JAMH through his inclusion of music and formal experimentation. Departing from previous scholarship that reads $J A M H$ as emblematic of the author's artistic decline, I interpret the novel's numerous syntactic and figurative experiments as offering new formal insight into his portrait of brotherly love. Baldwin's integration of two distinctive leitmotifs, blood and song, is therefore read as a formal gesture toward a more capacious and migratory kinship.
\end{abstract}

Keywords: kinship, diaspora, James Baldwin, Just Above My Head, Édouard Glissant, incest, music, blood, errantry

James Baldwin opens his 1979 novel Just Above My Head (JAMH) with a telling scene: an older brother, Hall Montana, alone in his home on a sunny morning, receives a long-distance phone call announcing his younger brother Arthur's untimely death in a London pub. From these first pages, readers are confronted with the painful experience of one sibling mourning the loss of another. ${ }^{1}$ The culmination of Baldwin's exploration of sibling bonds throughout his life, this, his

James Baldwin Review, Volume 3, 2017 @ The Authors. Published by Manchester University Press and The University of Manchester Library 
last published novel, examines how distance and loss serve as the true measures of love between brothers and sisters. Hall's first-person testimony illuminates his desolation after Arthur's death: "everything becomes unanswerable, unreadable, in the face of an event yet more unimaginable than one's own death. It is one's death, occurring far beyond the confines of one's imagination."2 Faced with this unimaginable loss, Hall embarks on a circuitous narratorial journey to reckon with the mysteries of his brother's life and relationships. By analyzing Baldwin's representation of Hall Montana's relation to, and mourning of, his brother, this article argues that $J A M H$ revises the terms of the African-American blood family to imagine an alternative, errant kinship that is adoptive, migratory, and sustained through songs of joy and grief.

Throughout $J A M H$, readers follow Hall as he traces Arthur's errant life trajectory, in the end finding not a single point, but a far-reaching network of intersecting characters and relationships. According to the Oxford English Dictionary, "errant" is defined as having "no fixed origin, or destination" and exhibiting a tendency to "stray from the proper course." ${ }^{3}$ An unusual musical pilgrimage that indeed strays, Hall's narrative mirrors Arthur's experiences wandering the globe as a gospel singer performing in the backwaters and cosmopolitan centers of North America, Europe, and beyond. While the brothers are bound by blood and genealogy, Baldwin crucially highlights the rootless and distanced aspects of their bond in order to reconceive brotherhood as a relationship defined as much by difference and separateness as by similarity, intimacy, and shared origin. Through his portrayal of these two African-American brothers, Baldwin further imagines black kinship as constituted from errant travels, both literal and metaphoric, which echo the wandering paths of diaspora. As the Montanas' trajectories suggest, the story of black kinship is never linear, nor direct, but rather a relational practice that crosses geographic, emotional, and spiritual distances. Baldwin's novel bears witness to how these journeys are characterized by the loss, mourning, and missed connections ever-present in African-American life; by doing so, the text envisions Arthur's surviving family members, though wracked with grief, still retaining a sense of spiritual connection with him after death.

This article's consideration of errant kinship in JAMH finds productive linkages between postcolonial theory and criticism and Baldwin's experimentation with literary form and black identity at the end of his career. Édouard Glissant's 1990 treatise Poetics of Relation is particularly helpful in defining "errantry" as a fundamental characteristic of diasporic life that resists the claustrophobic, filial violence and territorial dispossession that are slavery's legacies. ${ }^{4}$ My perspective on the novel is further indebted to what Glissant calls "relation identity": a poetic state of being with others that is catalyzed by errant movement, cultural hybridity, and multilingualism. ${ }^{5}$ In Poetics of Relation, Glissant thus articulates the ways that errantry is not simply a state of geographic instability or distance, but an experience of profound psychological flux, writing: "one who is errant (who is no longer traveler, discoverer, or conqueror) strives to know the totality of the world yet already knows he will never accomplish this-and knows that is precisely where 
the threatened beauty of the world resides." ${ }^{6}$ Here errantry resembles a quest to understand the world and the other, even while acknowledging the impossibility of this goal-an experience deeply reflective of Hall's often thwarted desire for a complete and mutual understanding with his brother. Throughout the text, both brothers, in their own way, seek that ethereal ability to "wander without becoming lost," as Glissant later describes."

Bearing the trace of Baldwin's other stories of sibling separation and loss, $J A M H$ recalls earlier portraits of the wayward love that brothers and sisters share, most notably Another Country (1962), “Sonny's Blues” (1965), and Tell Me How Long The Train's Been Gone (1968). Notably, the title Just Above My Head looks back to a scene in Another Country where the white protagonist, Vivaldo Moore, remembers his black lover Ida Scott singing the gospel song "Up Above My Head," popularized by gospel-crossover singer Sister Rosetta Tharpe, the lyrics of which read, "Just above my head, I hear music in the air. And I really do believe there's a God somewhere." ${ }^{\prime}$ This light, upbeat song conversely speaks to Ida's difficult burden of coming to terms with her brother Rufus's tragic death, illuminating an unspoken hope that love, music, and faith might eventually ease her grief. By pursuing a career as a jazz musician and entering into an interracial romance with Rufus's best friend, Vivaldo, Ida seeks to repair the rupture left after Rufus's suicide. Yet by the close of Another Country, her quest to find the heavenly source of that "music in the air" remains tragically incomplete. Extending Ida's song to his portrait of sibling mourning in $J A M H$, Baldwin picks up where her story ends and transports these lyrics to a different key, a key that departs from interracial community and instead captures the deep impact of racial subjugation on black kinship and collectivity.

Baldwin's novel of errant kinship grows out of his own nomadic life as an African-American queer expatriate who spent many of his adult years living and traveling abroad, often accompanied by his siblings. By crafting a narrative that circumnavigates the Atlantic, Baldwin implicitly contextualizes the novel's representation of familial loss and conflict within the history of enslavement and diaspora. As Cora Kaplan and Bill Schwarz attest, "There was [...] nothing rectilinear about Baldwin: neither in his conception of the world nor in the trajectory of his life." In a 1980 interview with Wolfgang Binder, Baldwin commented on the rootlessness of $J A M H$, speaking to the ways the Middle Passage inspired a new vision of kinship within the text:

[The novel] has something to do with the journey of a people from one place to another, a kind of diaspora which was unrecognized as yet, and in that journey what has happened to them and what has happened to the world as a result of their journey and is still happening to the world. They brought themselves a long way out of bondage by means of the music which $J A M H$ is at bottom about. ${ }^{10}$

Here, the author casts the Montana family's struggles within a broader “journey of a people from one place to another" that seeks to deliver them "out of bondage by 
means of the music" created in black diaspora. Baldwin depicts Arthur and Hall turning outside of their family circle to adopt black friends and neighbors as their kin, questioning the strict forms of blood kinship and genealogical inheritance that were often the sinister instruments of slave bondage. This narration of the love and nomadic travels shared by Hall, Arthur, and their elected kin de-centers a Euro-American understanding of familial relation and consequently re-centers the black diaspora as a framework for cultivating a more heterogeneous and expansive form of kinship. ${ }^{11}$

As suggested in his 1980 interview, Baldwin expresses this theme of errant kinship in JAMH through his incorporation of music and formal experimentation. Breaking open the English language in his use of syntactic fragmentation, orality, and interposed musical lyric, Baldwin's literary experimentation reflects what Glissant terms a "counter-poetics"-a daunting, if not impossible, project to find a new language capable of imagining a practice of relation that fundamentally resists dominant Western culture and history. ${ }^{12}$ Considering the historical moment out of which JAMH emerged, the novel's emphasis on gospel and the blues, in particular, points to Baldwin's authorial effort in later life to write in a de-colonized English language that incorporated the black vernacular. In the same month as the novel's completion in 1979, Baldwin published an essay in The New York Times entitled “If Black English Isn't a Language, Then Tell Me, What Is?" in which he argued that people construct languages from "brutal necessity" to resist subjugation-language comes into being so that individuals can "confront life, in order, not inconceivably, to outwit death."13 Writing against the monolingual authority of "white" English, Baldwin illustrates how black kinship necessitated a new language that he notably calls an "incredible music." ${ }^{4}$ In Baldwin's eyes, this language must be relational and plural, for it responds to "the creation of a black diaspora. Blacks came to the United States chained to each other, but from different tribes: Neither could speak the other's language."15

Evincing Baldwin's political and artistic struggle to find a new language for diasporic black identity and kinship after violence ruptured 1960s movements for racial justice, $J A M H$, for some critics, approached artistic failure. John Romano in his September 1979 New York Times review stresses Baldwin's supposed inability to capture the "concreteness" of historical reality, in the end arguing for the novel's incoherence: "No one, I think, will find this novel consistently absorbing or entertaining or insightful, though it is all of those things in places." ${ }^{16}$ Challenging these early critiques of the novel, almost thirty years later scholar Robert Reid-Pharr claimed that the formal incoherence found in parts of JAMH is in fact representative of the oppressive racial conditions that contributed to Baldwin's alienation and consequent artistic decline. ${ }^{17}$ While I concede that the novel in some ways can appear structurally incoherent and overwrought when compared to his earlier protest novels like Another Country, Baldwin at the same time productively infuses the text with powerful extended metaphors as well as poetic and musical lyric in order to invoke the "incredible music" of diasporic forms of communication. In her 1987 memorial essay written upon Baldwin's death, Toni Morrison 
testifies to his gift of "un-gating” American English for black people, reflecting on the way his writings gave African Americans "a language to dwell in," and continuing: "In [his] hands we saw how [language] was meant to be: neither bloodless nor bloody, and yet alive." 18 Invoking what Morrison elsewhere calls a "living language," Baldwin experiments with form in $J A M H$ to resist the dead linguistic registers of white supremacy. ${ }^{19}$

In my reading of the novel, I argue that Baldwin's numerous syntactic and figurative experiments should be regarded as new formal insights into the representation of errant kinship. In the following pages, I show how JAMH's trajectory from a wounded, claustrophobic vision of blood family toward a more capacious and migratory kinship is represented formally through Baldwin's integration of two distinctive, yet interconnected leitmotifs of blood and song. Characterizing the first half of the lengthy novel, the figuration of blood articulates the racial violence and risks of familial loss and injury that overshadow Hall and Arthur's bond; here, Baldwin's narrative emphasizes the ways the brothers' kinship emerges out of and is defined against a tragic father/daughter incest story that occurs between the Montanas' close family friends, Julia and Joel Miller. These intersecting plots illustrate the structural violence leveled at the black family, which Baldwin seeks to resist in his invocation of the musical traditions of gospel and the blues. In order to counteract the confinement and danger that these blood genealogies can sometimes inspire, Baldwin increasingly incorporates vocal performances and song lyrics as the narrative progresses into the novel's second half, thereby infusing his novel of errant brotherhood with an expansive, far-reaching spirit that sustains deep feelings of connection.

To look first at the novel's early chapters, readers encounter a figural pattern of blood and filiation that serves as the narrative foil against which Baldwin imagines the brothers' relationship as shaped by a broader circle of kin. According to the etymological origins of the English term "blood," the meaning of the word has always related to ideas of lineage; thus blood seems an obvious metaphor through which to imagine vertical, filial ties. ${ }^{20}$ Yet in Baldwin's use of the metaphor in $J A M H$, blood symbolizes how everyday life is shaped by horizontal systems of racial and sexual violence as well as the lateral, adoptive structures of relation that work to assuage loss and injury. Emblematic of these horizontal structures of affiliation, Hall's narration of his brother's life and his own mourning opens up their bond to an intimate social network that includes many friends and lovers: the Miller family made up of siblings Julia and Jimmy Miller, who become lovers with Hall and Arthur, respectively; Arthur's teenage musical collaborators Red, Peanut, and Arthur's first queer lover, Crunch; and the arrival of new connections in Hall's marriage to his wife Ruth and the birth of their children, Tony and Odessa.

Baldwin's revision of black kinship to emphasize adoptive bonds of relation turns on an unsettling depiction of inter-generational incest in the first half of the novel. In contrast to the joy, duty, and care alive in the Montana family, their Harlem neighbors, the Millers, witness their family life implode after the death 
of the mother, Amy, and the father Joel's sexual abuse of his daughter, Julia. The aberration of blood lineage found in this father/daughter incest plot, and Julia's ensuing infertility, participates in a long-standing African-American literary trope. In her essay "In the Time of the Daughters and Fathers," Hortense Spillers argues that portrayals of incestuous relations between fathers and daughters speak to the destruction of black paternity under slavery that continues to overshadow black filiation today. ${ }^{21}$ Similarly for Glissant, the plot of incest in Western literature, such as in Faulkner's Absalom, Absalom!, is the quintessential sign of the dangers of white filiation; he writes in Poetics of Relation: "all the interpretations (of our societies) dominated by themes of filiation [...] epitomize ethnocentric and frequently naive projections of Western thought." 22 I argue instead that the novel's lengthy and fragmented incest plot opens the door to new modes of intimate belonging among the surviving members of the Miller and Montana circles.

In order for his portrait of father/daughter incest between Joel and Julia to illustrate the ruptures that occur in the black family under white supremacy, Baldwin casts the Millers' home as threatening and oppressive-a metonym of their imploding family. In Hall's memory of visiting their chaotic flat in Harlem one Christmas Day in the 1940s, a sense of claustrophobia rises to the surface and foreshadows Julia's eventual victimization:

There were plants growing in boxes on the windowsills; it was not so much a cluttered as a buried, a secret house. Even the clothes that Brother Joel wore contributed to this airless, hot-house climate, for-they covered him: one did not wish to speculate on his nakedness, or find oneself, in any way whatever, obliged to be a witness to it. (p. 113)

Here in the "airless," threatened Edenic climate that "was so cluttered with such incredible shit that it needed a guide," Joel lives with a buried secret that will eventually materialize and oblige Hall, Arthur, and the reader to "be a witness to it." The Miller home signifies the familial insularity Baldwin seeks to resist, the insularity harkening back to the plantation that Glissant similarly describes as "an enclosed place" where "airtight seals were apparently the rule."23

Over one hundred pages later, the novel's incest plot concludes with the apartment steeped in the figurative language of blood, which underscores the potential violence of a black kinship that remains haunted by the horrors of its plantation past. When Julia becomes pregnant by her father, his refusal to bear the truth of his aberration translates into an attack on his daughter that leads her to lose the fetus and suffer serious injury. Hall's mother narrates her memory of coming to Julia's aid, recounting to Hall how her "blood just stopped and froze" when she realized who was responsible for the girl's wounding. Florence then turns over the story to her husband Paul, who describes the space: "I mean it was a slaughterhouse ... there was still blood on one of the windows, blood in the sink, blood on the sofa" (pp. 303-4). Now undone by Joel Miller's sexual and physical abuse, the home becomes a place bloody with injury. In turn, this domestic "slaughterhouse" 
is paralleled in Baldwin's depiction of Julia's hemorrhaging body and womb: her face "was just a mess of blood and puffed-up flesh." Florence states: "I wrapped the child as best I could, in blankets-and the blood came seeping through those blankets, I just knew she was going to bleed to death-and then, for the first time, what she'd been saying about losing a baby made sense, she was bleeding heavy from between her legs" (p. 303). House and body metaphorically united, the terms of blood mark the final loss of vertical lineage, for Julia's "bloody passage to womanhood" heralds the end of her reproductive life, and of the Miller line (p. 326).

Baldwin's representation of incest underscores the bloody, violent fate of black kinship when it fails to fully recognize, and instead struggles against, the social and familial aftermaths of slavery. Spillers writes: "Whenever incest occurs as a fictional/symbolic motion [...] The shape, the outline [of kinship], melt down in an inexorable play of sameness, of identities misplaced and exchanged." ${ }^{24}$ She goes on to argue that incest in African-American literature-of which she cites $J A M H$ as one example-articulates an abiding "loss, confusion [...] and imposed abeyance of order and degree." ${ }^{25}$ Rather than become victim to the loss of identity and collectivity that de facto structures of racial segregation inevitably produce, the Montanas' familial dynamic resists the collapse of subjectivity and difference that is embodied in the Millers' story. It is crucial, then, that the novel turns away from a plot that accounts for the rupture of vertical, reproductive kinship and turns toward the story of a horizontal, brotherly love.

Hall and Arthur's relationship departs from a closed-in vision of blood family to instead resemble a queer bond defined by difference, distance, and collaboration. In the context of the brothers' journey, Baldwin's figuration of blood speaks then not only to the genealogical bond the brothers share, but more directly to the dangers of racial violence that eventually contribute to Arthur's fall. Baldwin casts the opening scene of Arthur's death in similarly bloody terms:

The damn'd blood burst, first through his nostrils, then pounded through the veins in his neck, the scarlet torrent exploded through his mouth, it reached his eyes and blinded him, and brought Arthur down, down, down, down, down. The telephone call did not go into these details, neither did the telegram: urgently demanding my arrival because my brother was dead. (p. 3)

Baldwin's use of blood imagery shows the thematic interconnections between Julia and Arthur's fates, while revealing the ways black kinship in the text is structured by the terms of racial subjection. His detailed depiction of Arthur's heart attack further highlights the breakdown of signification that haunts the narrative's portrayal of kinship. Baldwin's lyricism transports Hall to the scene of "burst blood" and magnifies the body's interiority; we witness with Hall the "scarlet torrent" first exploding in Arthur's mouth that renders him inarticulate, and then reaching his "eyes" that blinds us from fully perceiving the event. His blood ostensibly becomes a barrier to communication, symbolizing the gaps in experience and the geographic distance that exists between the brothers. Expanding the connotation 
of blood as vertical lineage or passing down of family history, Arthur's bloody death in the basement bathroom of a London pub brings him "down, down, down, down, down" both literally and figuratively. He symbolically succumbs to the force of racial subjugation that Baldwin elsewhere compares to a "rung-by-rung" descent: "the Negro tells us where the bottom is: because he is there, and where he is, beneath us, we know where the limits are and how far we must not fall." ${ }^{26}$

Blood is not just the vehicle of Arthur's demise but a figure indicative of the vulnerability that the brothers share living in a racist society where black men often die too soon. After learning more of the immediate circumstances of Arthur's death so far from his New York home, Hall laments their shared corporeality: "He had been found lying in a pool of blood-why does one say a pool? - a storm, a violence, a miracle of blood: his blood, my brother's blood, my brother's blood, my brother's blood! $M y$ blood, my brother's blood, $m y$ blood, Arthur's blood, soaking into the sawdust of some grimy men's room..." (p. 4). Mirroring the incestuous breakdown of identity, Baldwin blurs the boundaries between the brothers, as Arthur's death seems to threaten Hall's survival. The repetitive play of "my blood" here disorients the reader's capacity to distinguish between "mine" and "yours," between what's familiar and far-off. While the passage dramatizes the brothers' genetic similarity in the repetition of "blood," the poetic inversion of the line "his blood, my brother's blood" points to the dislocation present in their imagined union. The description challenges idiomatic norms, suggesting that the "pool of [Arthur's] blood" is unbounded: it is "a storm, a violence, a miracle." This metaphoric phrase inspires a sense of physical and linguistic plasticity, where the bounds of blood kinship are dynamic and changeable, transporting Hall symbolically to his brother laying dead across the Atlantic and to those other victims of racial violence across the diaspora.

Hall's intimate effort to bear witness to his brother's wounds thus calls in other people and places, reflecting the way their sibling bond connects them to a broader system of power and relation. As a young man making his way in post-war Manhattan, Hall must navigate a similar landscape of racial violence to the one that contributes to Arthur's downfall. In one scene bearing witness to workplace racism, Hall experiences a "blood-red thunder" that rolls "all around" him when he is overcome by a desire to mortally attack an ignorant white boy who calls him "shine" (p. 81). Years later, when accompanying Arthur and his friend Peanut on a second gospel tour to the Jim Crow South, he hears Arthur sing in testimony to this violence. Baldwin writes: "Arthur paused, threw back his head, throwing his voice out, out, beyond the motorists and the governor, and the blood-stained trees, trees blood-stained forever" (p. 409). Here the repetition of "blood-stained" marks the legacy of plantation violence: the lynching of African Americans. As blood comes to symbolize the broader structures of power that render black kinship and black life all too precarious, Baldwin transmutes this narrative of one brother's mourning into a collective journey of liberation.

Although the novel's social landscape is marked with the wounds of racial violence, it is the arrival of music that brings the potential for emotional change 
and spiritual movement to this circle of kin. This movement can be found in the scene above, where the literalism of blood and wounding is transformed through Arthur's gospel song that is "thrown out, out, beyond" this particular geography onto a space elsewhere. As Ed Pavlić writes, Baldwin's lyric style seeks “an imagined balance, which allows things, real things, to come and go. The basic phase change (from pain to joy) of lyricism: solid pain made fluid. Joy." 27 Through this lens, the poetic lyricism found in these formally complex passages builds on the affective connotations of blood to express Hall's emotional journey of letting Arthur's life and death "come and go." Baldwin's use of blood imagery when narrating "real" attributes of setting and character is juxtaposed, though, with its meta-textual invocation in the gospel songs that Arthur sings, such as "God Leads Us Along." Illustrative of God's redemptive power, blood now heralds the ultimate threshold between life and death: "God leads his Children along. Some, through the water, some, through the flood. Some, through the fire, but all through His blood," and later, "Have you been through the fire? Are you washed in His blood?" (p. 407). Combining the immanent and the transcendent, the corporeal and the ethereal, Arthur's song expresses the spiritual mystery that begins to transform blood ties into a more expansive, errant kinship that can withstand loss and estrangement. Rather than simply revealing the tragic fall caused by subjugation or death, this song thus looks upward toward the ethereal world "just above" our heads.

Arthur and Hall's relationship illuminates how the transcendent tones of black kinship can only be heard when set alongside the material suffering and estrangement that comes from loving and losing others, whether it be from geographic and social division, or death. The loss and fragmentation present in the plot of $J A M H$ echo Baldwin's experiments with a figurative language interposed with musical lyric, which is better able to bear witness to a history of race in America that Baldwin, in "The Uses of the Blues," terms "bloody": "it's a bloody history, as bloody as everybody else's history, as deluded, as fanatical." ${ }^{\prime 2}$ For as he argues in this 1964 essay, any white, American dream of escaping the inevitability of being "hurt" or being "made to bleed" is antithetical to the real, difficult work of belonging in this nation. More importantly, Baldwin casts music as the "toughness" needed to survive and articulate the brothers' journey of relation. Describing the blues as a relational practice of exchange, Baldwin compares its power to the singer's embodied capacity to connect to the audience. He writes:

it's this passionate detachment, this inwardness coupled with outwardness, this ability to know that, all right, it's a mess, and you can't do anything about it ... so, well, you have to do something about it. You can't stay there, you can't drop dead, you can't give up, but all right, okay, as Bessie said, "picked up my bag, baby, and I tried it again." 29

To have "passionate detachment" is for the singer to hold within her an intimate distance from the other, which allows her to sing her song even in the face of oppression. Moreover, this sense of "passionate detachment" is depicted in 
metaphors of movement and flight, when all that's left to do is “pick up [one's] bag" and try again.

In $J A M H$, this "inwardness coupled with outwardness" and sense of wandering is illustrated not only in the experimentation with metaphor that Baldwin incorporates throughout, but also in the syntactic breaks and disjunctive narrative movement through which characters voice their experience. It is Arthur, the "brother saint" as Morrison describes him, who most often performs this "passionate detachment" in his gospel songs that inspire listeners to notice the transcendent in the everyday. ${ }^{30}$ Even as a young boy, Arthur inhabited the in-between: as a youth he is compared to "an insect with translucent wings [...] making of air, light, space, and danger, a province, a kingdom" that Hall regarded from a position "rooted to the earth, follow[ing] without moving" (p. 140). Arthur's otherworldliness makes him a keen observer of the world, much like a performer taking the measure of his audience and venue. In turn, Arthur is spiritually estranged due to his defiance of social mores and the vulnerability he carries as a gay black man. Arthur's way of being teaches Hall that he too must inhabit the crossroads of life and death, which are often the subject of gospel and blues. For in order to complete the narrative, Hall must begin to occupy the "air, light, space" that characterized his brother's art and life. His narratorial struggle against the racial systems of subjugation that contributed to Arthur's death thus requires him to invite in other voices and textual registers, whether they be conjured in music, speech, or song.

As the novel progresses, Baldwin's invocation of gospel and the blues encompasses a more capacious vision of love and mourning in the text. Through these hybrid musical registers, a new mode of relation is cultivated that can more deeply reckon with the distances of history and geography that shape black life. ${ }^{31}$ In the depiction of the brothers' errant kinship in JAMH, voices travel, intermingle, and sometimes merge; often, they appear disembodied in their ability to transpose from one place or key to another. At times they are mediated or recorded, and at other times they are alive, joyously free. It is live, embodied song that serves as the most powerful, most intimate, and yet fleeting vehicle for characters to relate to each other in Baldwin's fiction. As D. Quentin Miller suggests in his historical account of Baldwin's use of the blues: "the emotional impact of live performance is more profound" in Baldwin's oeuvre. ${ }^{32}$ In fact, JAMH incorporates live music perhaps more than any other of Baldwin's texts, due to its length and harmonic, syncopated structure. ${ }^{33}$ Approaching Baldwin's invocation of blues and gospel songs from a poststructuralist angle, Fred Moten writes of the holistic and aural power of black music in $J A M H$, the sound of which resists Eurocentric structures of linguistic signification. ${ }^{34}$ In my view, scenes of vocal performance, whether offered on stage or improvised at home, serve as the narrative register through which Hall and Arthur Montana's lives intimately mix. ${ }^{35}$

Baldwin's extensive use of black musical forms in JAMH illuminates another important feature of errant kinship: the migratory journeys characters like Arthur, Julia, Hall, and Jimmy undergo throughout their lives. Traversing spiritual and 
geographic distances, their live voices reflect a diasporic movement, for music is often found in crucial moments when characters are either leaving or returning from international travel. This dynamic can be found in one scene where Arthur sings to Hall upon Hall's return from serving in the Korean War:

\section{Shine,}

looking at me for a second, and at the space behind me, then back down to the keyboard,

on me.

I watched his fingers on the keyboard. His eyes were closed.

Shine

on me.

I watched his face and his hands, as though I had never seen them before, and felt him beginning to drag his song up out of me.

Let the light

from the lighthouse

shine on me. (p. 308)

Reunited after a long absence, Arthur and Hall connect through the performance of Arthur's ballad, which is not only Arthur's, but a collective song that Hall feels being "drag[ged] ... up out of [him]." A stirring force that both interrupts and animates the forward movement of the story, the italicized music inspires both fragmentation and coherence. Further, Arthur's interpenetrative song infuses Hall with a feeling of sensual recognition that invites reciprocal acts of testimony and witnessing.

This narrative pattern of employing song in moments of reunion among the Montanas' extended circle of kin is continued much later in the novel, when Hall sees Julia after her return to New York after living for years in Abidjan. Prior to her departure, Hall and Julia's adolescent friendship had matured into a deep romance, which in the end could not be sustained. Now, their re-acquaintance inspires a new sense of loving kinship that subverts heterosexual convention. Baldwin interweaves the description of their meeting with lyrics: "Drink to me only with thine eyes - that ridiculous song suddenly made sense to me. And I will pledge with mine. Then I took her in my arms, and we kissed each other, like brother and sister" (p. 544). Hall and Julia's pledge of care for each other revises the novel's filial incest plot in the service of an adoption made possible by distance and parting; the italicized lyrics that break up the syntax symbolize the separation that now introduces a new form of relation.

Baldwin's incorporation of song serves as more than a medium for engaging with loved ones, despite geographic or temporal distances. As is seen above, this music also crucially opens up a shared space of intimacy and sensuality that catalyzes modes of affiliation beyond blood relations. In $J A M H$, scenes of loving relation include those shared between Hall and Arthur, for example, but also those moments of sexual intimacy among lovers. The novel's most profound sexual representations occur between Arthur and his first lover, Crunch, who fall in love and 
consummate their union while on tour in the southern U.S. with their quartet, The Trumpets of Zion. On the road, the characters' acknowledgement of the "great new space opening before them" exists in stark contrast to the inhospitable Jim Crow world outside their boarding house door (p. 191). Upon realizing his queer love for Crunch, and his subsequent fear of losing him to another, Arthur experiences a sense of spatial and vocal disequilibrium that evokes the novel's title: "he heard his voice falling all around his ears from about twenty-seven million miles above his head; his feet, just the same, seemed to be on the ground" (p. 194). This spatial instability that resembles the "inwardness coupled with outwardness" of the blues foreshadows the lovers' eventual sexual encounter pages later, which Baldwin describes as a long train journey to an "unimaginable place" (p. 210).

Baldwin's expansion of spatial and temporal borders in their sexual encounter is predicated again on the syncopated incorporation of gospel strains. Reminiscent of other moments of syntactic fragmentation, Arthur and Crunch's sexual climax is interposed with the song "So High." After incorporating the italicized term "cocksucker"-connoting the potential shame each character fears will be unleashed against their same-sex desire-Baldwin connects this homophobic slur with the song's first lines, queering the gospel tradition to convey a different kind of revelation. Baldwin continues, interrupting the line's flow:

\footnotetext{
A friendly, a joyful movement, began. So high, you can't get over him. Sweat from Arthur's forehead fell onto Crunch's belly.

So low-and Crunch gasped as Arthur's mouth left his prick ... you can't get under him. Arthur rose, again, to Crunch's lips. So wide. You can't get around him. It was as though, with this kiss, they were forever bound together ... you must come in at the door. (p. 211)
}

Here Arthur and Crunch experience the ecstatic disorientation that comes with sexual pleasure. The unfolding spatial references found in the italicized quoted lyrics from "So High" symbolize their lovemaking, as Crunch's sex seems to extend everywhere. ${ }^{36}$ Baldwin re-appropriates this gospel tune to convey the ecstasy that fills the scene, the lyrics echoing the image of some spirit hovering "just above my head." In signifying the highs and lows of a new romance, there is also a touch of the blues in these lines that muddles the distinction between up from down, inside from out. Against the legislated public limits on black life at mid-century, Arthur and Crunch experience a private, erotic freedom, escaping into each other as they move outward, toward another country. And yet, even in its profundity, their love affair is temporary, for upon their return to Harlem and Crunch's departure to serve in the Korean War, the lovers move on to new relations and responsibilities.

In following Arthur's erotic development throughout the text, Baldwin illustrates that it is not just the peripatetic movement of diaspora that shapes the errantry of black kinship, but the fragmentary power of black queer desire. ${ }^{37}$ As Hall describes Arthur's itinerant lifestyle as a gay black man: "his life then seemed to him to be nothing more than a series of ruptures" (p. 471). The narrative of 
Arthur's life and death illustrates how his blood and adoptive families, the Millers and Montanas, are intertwined not simply through their co-witnessing of each others' suffering, but in the siblings' intimate relation to each other that is touched by the dynamism of queer desire. Faced with loss and suffering, Hall and Julia and Jimmy and Arthur's relationships endure only when they surpass the limits of the physical and material realms and engage with the distant "music in the air." The various erotic ties that connect these characters across genealogical lines serve as the sensual threshold through which they can reach a new form of spiritual relation. If we are to dwell "within the relationships of the brothers, the two families," as Baldwin describes of JAMH, we must reflect on the ways the novel portrays this haunting "cloud of witnesses to a particular assessment of possibilities," the most notable of which is death. ${ }^{38}$ Baldwin asks readers to bear witness to their collective mourning song, which as we engage more deeply with the novel becomes, in part, our own.

By the novel's close, Baldwin has offered up a contrapuntal song of love and death, carrying the reader on a journey through the bloody consequences of black genealogies fractured by historical violence toward the music that opens up an alternative, errant kinship. Enduring bonds of relation in $J A M H$ are not defined by simple notions of familiarity or proximity; for this essay's formal reading has sought to present a kinship forged in musical alchemy-one that is porous, mobile, and able to embrace the other, who is also our brother. From Hall's earliest memories of listening to his father play in piano bars or his baby brother sing in church, the gospel, jazz, and blues that are interwoven throughout the novel facilitate feelings of kinship even after death. After a long peripatetic journey, the reader arrives at a fragmented vision of kinship that can only be sustained through spirited acts of testimony and song. For, as Glissant's translator Betsy Wing suggests, errantry "is not idle roaming, but includes a sense of sacred motivation" toward a more perfect form of relation, however transitory it may be. ${ }^{39}$

The novel's journey of errant kinship concludes with a sequence of musical voices that ring out across temporal, spatial, and emotional breaks. While the majority of the novel foregrounds Hall and Arthur's perspectives, by its close the narrative becomes ever more permeable, with new voices entering the scene. One of these voices emerges during Arthur's stay in Paris, when he visits a jazz bar with his French lover to hear the famous jazz singer, Sonny Carr, who sang at one time with his father decades before in Harlem. Sonny performs "Yellow Dog Blues," made famous by Bessie Smith, which invokes the pain and pleasure of a lover's departure. ${ }^{40}$ Baldwin interposes Sonny's song in italics throughout the scene: "you can hear her moanin' night and morn. Wonder where my Easy Rider's gone?"; then a few sentences later "All day the phone rings, but its not for me"; and finally "He's gone where the Southern 'cross' the Yellow Dog" (p. 508). Echoing the spiritual strain of what Baldwin elsewhere calls the "heavenly telephone," this song suggests feelings of abandonment and disconnection. Its lyrics foreshadow the way Sonny's performance, as metonymic of the novel's larger elegiac journey, leaves "all possibilities open, or all possibilities closed" (pp. 341, 509). At the scene's 
close, Arthur replies with his own gospel hymns that herald a kind of worldly collapse-prefiguring his passing, but also the possibility of entering a different world, free from suffering. After Arthur sings a couple of numbers, Sonny joins in to help him bring home the final prophecy: "I'm pleased with what you've done, and your race has been run and I've brought you the key and I've got your key here with me and I praise God, I have another building, not made with hands!" (p. 513). Singing out, the two men testify to the way Arthur's final journey will take him to that divine and transcendent house "not made with hands," nor circumscribed by geographic or material boundaries.

While Sonny's song inspires Arthur to reflect on the possibilities and dangers of his own soon-to-be-ending musical path, the arrival of Jimmy Miller's voice pages later invites the reader to consider the possibilities and limits of the novel itself. In the novel's conclusion, Hall relinquishes his narrative to Jimmy-Arthur's longtime lover-who more than any other character can testify to the lower frequencies of Arthur's cry. Jimmy's first-person voice introduces an unmediated queer point-of-view, his love for Arthur intimately folding into Hall and Arthur's brotherly affiliation. Telegraphing Arthur's voice in song, Jimmy states:

Every inch of Arthur was sacred to me. And I mean: sacred. I will testify that, to all the gods of the desert, and, when they have choked my throat with sand, the song that I have heard and learned to trust, my friend, at your brother's knee, will still be ringing. And will bring water back to the desert, that's what the song is supposed to do, and that's what my soul is a witness is about. Think about where you would have had to go, to put those five unrelated words together, and make of the connection, a song. (pp. 576-7)

Testifying to the love song he learned "at [Arthur's] knee," Jimmy illuminates the prophetic nature of Arthur's voice that "will still be ringing" even after the novel's close. His song is so powerful that it can resist the judgmental gods who might "choke [his] throat with sand," as it bears witness to the "sacredness" of the men's love and their intertwined refrains. It is only once Jimmy is brought into the fold of the narrative that the text arrives at this open and sacred resolution, his vocal testimony serving as the novel's bridge that prepares us for the climactic, yet profane, scene of Arthur's actual death, which we have been waiting for since the first page. As Baldwin writes: "The journey across the room is the longest journey he has ever forced himself to make. He starts down the steps, and the steps rise up, striking him in the chest again, pounding between his shoulder blades, throwing him down on his back, staring down at him from the ceiling, just above his head" (p. 582).

What is it to listen and be a witness to this painful song? From Jimmy's standpoint, the revelatory experience of listening challenges readers to bear witness to, and to thereby become accountable for, Arthur's tragic fate. For throughout the novel we are asked to "think about where you would have had to go" to truly hear and consequently respond to this sorrow song (p. 576). Within Hall's broader 
narrative, Jimmy offers up an errant refrain that self-reflexively attends to the silences and breaks that constitute loving another in the face of suffering, absence, and death. He thus testifies to the fact that without accounting for the differences and fragments that shape families and communities, the real terms of our relation remain hollow. Like Hall's capacious answer to the metaphoric call of the "heavenly telephone" in the novel's opening announcement of Arthur's death, the novel's conclusion leaves readers with the burden of becoming both the singer and a listener closely attending to the arrival of other voices and new songs. As Jimmy reminds us: "the song does not belong to the singer. The singer is found by the song" (p. 576). Like the call to a sacred journey, Baldwin's novel seems to wander "like music in the air," hovering above us until it finds that listener who can pick it up and sing.

After Jimmy's riff, the novel concludes with Hall dreaming of a final reunion with his brother, where Arthur reminds him that the only thing that's up the road "is us." Hall awakens in the last paragraph to find his brother absent and his "pillow wet with tears"- this desolate ending serving as testament to Hall's irreparable loss (p. 584). Echoed in the absence of the characteristic geographic signature that Baldwin often included on the final page of his novels, Hall's abandonment upon waking mirrors the reader's, as we leave the text to return to the pain and contradictions of everyday life. And yet, as we are about to leave the scene, the motif of tears circles us back to a moment five hundred pages or so earlier, where we might remember a different moment of awakening and a different set of tears:

I miss him, miss, miss, miss, miss him, miss him worse than you miss a toothache, worse than you miss the missing tooth, worse than you miss the missing leg, even worse than you miss the stillborn baby. His voice is everywhere, but not even the voice can fill that space in which Arthur moved and walked and moaned and talked and belched and farted and pissed and shit and wept and wept and wept and wept and wept ... striding, striding, striding, in his big, flapping traveling shoes, all, all over my heaven. (pp. 21-2)

We are returned, in this early passage, to Hall's cries for his younger brother, where he compares the experience of mourning to amputation. At the same time, he remembers his brother as vibrantly alive - a talking, belching, weeping soul. Moving from the long, disjunctive sentence of the pain of "missing," we quickly encounter Arthur's voice that "is everywhere" and nowhere, as well as the stark impossibility of ever "fill[ing] that space in which Arthur moved and walked and moaned" and wept again and again. And yet, among these irreparable losses, the novel's peripatetic spirit is present still in this snapshot of Arthur weeping, yet wonderfully on the move. An unmistakable errant traveler, Arthur "strid[es] in his big, flapping traveling shoes" across the space "just above" our heads, wandering the realm of "heaven" that is Hall's and Jimmy's, and now the reader's, to reveal. 


\section{Notes}

1 The novel's dedication emphasizes this project, dedicated as it is to Baldwin's three brothers and five sisters, as well as to two adopted kin, Bernard Hassell and Max Petrus. Like all of Baldwin's works, JAMH's portrayal of kinship unavoidably reflects back on the author's own life and close-knit relationships with his many brothers and sisters. While the biographical is an important scholarly context for Baldwin studies, for the purposes of this essay my argument will focus mainly on the formal and theoretical characteristics of the theme of kinship. For an overview of Baldwin's relationships with his siblings, see David Leeming, James Baldwin: A Biography (New York, Random House, 1994).

2 James Baldwin, Just Above My Head (New York, Random House, 1979), p. 4. Italics in original. All subsequent quotations are taken from this edition. Page numbers are given in parentheses in the text.

3 “errant, adj.," OED Online (Oxford, Oxford University Press, June 2016).

4 A Martinican poet, critic, and young member of the negritude movement, Glissant was a contemporary of Baldwin's and takes part in a larger Caribbean scholarly conversation about the role of linguistic experimentation in grappling with the legacy of enslavement in diaspora.

5 Edouard Glissant, Poetics of Relation, trans. Betsy Wing (Ann Arbor, MI, University of Michigan Press, 1997), pp. 18-19.

6 Ibid., p. 20.

7 Ibid., p. 203.

8 James Baldwin, Another Country (New York, Vintage, 1993), pp. 312-13; Sister Rosetta Tharpe's version of "Up Above My Head" is available online: www.youtube.com/ watch?v=Ls53x9nybec (accessed 15 March 2017).

9 Cora Kaplan and Bill Schwarz, "Introduction," in Cora Kaplan and Bill Schwarz (eds.), James Baldwin: America and Beyond (Ann Arbor, MI, University of Michigan Press, 2011), p. 2.

10 James Baldwin, "James Baldwin: An Interview," in Fred L. Standley and Louis H. Pratt (eds.), Conversations with James Baldwin (Jackson, MS, University of Mississippi Press, 1989), pp. 190-1.

11 Kevin Birmingham's discussion of Baldwin's literary exploration of diaspora has been helpful to my analysis here. Kevin Birmingham, "'History's Ass Pocket': The Source of Baldwinian Diaspora," in Kaplan and Schwarz (eds.), James Baldwin: America and Beyond, pp. 141-58.

12 Celia M. Britton, Edouard Glissant and Postcolonial Theory: Strategies of Language and Resistance (Charlottesville, VA, University of Virginia Press, 1999), pp. 181-2.

13 James Baldwin, “If Black English Isn't a Language, Then Tell Me, What Is?" in Collected Essays, ed. Toni Morrison (New York, Library of America, 1998), pp. 782, 780.

$14 \mathrm{Ibid}$. See also Glissant's conception of diaspora as made up of a diversity of languages and vernaculars. Glissant, Poetics of Relation, p. 19.

15 Baldwin, "If Black English Isn't," p. 782.

16 John Romano, "Just Above My Head," The New York Times, 23 September 1979, www.nytimes.com/books/98/03/29/specials/baldwin-above.html (accessed 10 January 2016).

17 Robert Reid-Pharr, Once You Go Black: Choice, Desire and the Black American Intellectual (New York, New York University Press, 2007), p. 114. For further discus- 
sion of Baldwin's engagement with the protest novel, see Robert J. Corber, "A Negative Relation to One's Culture: James Baldwin and the Homophobic Politics of Form," in Homosexuality in Cold War America: Resistance and the Crisis of Masculinity (Durham, N.C., Duke University Press, 1997).

18 Toni Morrison, “James Baldwin: His Voice Remembered; Life in His Language," The New York Times, 20 December 1987, p. 27.

19 Toni Morrison, "The Nobel Lecture in Literature" (1993), in What Moves at the Margin: Selected Nonfiction, ed. Carolyn C. Denard (Jackson, MS, University of Mississippi Press, 2008), pp. 198-208.

20 "blood, n.," OED Online (Oxford, Oxford University Press, June 2016).

21 Hortense Spillers, "In the Time of the Daughters and Fathers," in Black, White and In Color: Essays on American Literature and Culture (Chicago, University of Chicago Press, 2003), pp. 230-50. Aliyyah Abdur-Rahman provides a thoughtful analysis of the incest plot and provides additional support for this claim; see Aliyyah Abdur-Rahman, Against the Closet: Identity, Political Longing, and Black Figuration (Durham, N.C., Duke University Press, 2012).

22 Glissant, Poetics of Relation, p. 59.

23 Ibid., pp. 64, 65.

24 Spillers, "In the Time of the Daughters," pp. 241-2.

25 Ibid., p. 249.

26 James Baldwin, "In Search of a Majority," in Morrison (ed.), Collected Essays, p. 218.

27 Ed Pavlić, Who Can Afford to Improvise? James Baldwin and Black Music, the Lyric and the Listeners (New York, Fordham University Press, 2015), p. 156.

28 Ibid., pp. 61, 64.

29 James Baldwin, "The Uses of the Blues," in The Cross of Redemption: Uncollected Writings, ed. Randall Kenan (New York, Pantheon, 2010), p. 59.

30 Morrison, "James Baldwin," p. 27.

31 Glissant speaks of the necessary distance present in black diasporic kinship. Glissant, Poetics of Relation, pp. 153-7.

32 D. Quentin Miller, "Using the Blues: James Baldwin and Music," in Douglas Field (ed.), A Historical Guide to James Baldwin (Oxford, Oxford University Press, 2009), p. 87.

33 Keith Clark's discussion of JAMH alludes to the question of song, particularly in his claim that JAMH is Baldwin's most "speakerly" novel. K. Clark, Black Manhood in James Baldwin, Ernest J. Gaines, and August Wilson (Champaign-Urbana, IL, University of Illinois Press, 2004), p. 50.

34 Fred Moten, In the Break: The Aesthetics of the Black Radical Tradition (Minneapolis, MN, University of Minnesota Press, 2003), pp. 171-91.

35 Rashida Braggs's exploration of dislocated listening in Baldwin's short story “Sonny's Blues" has been helpful in providing further context for Baldwin's turn toward the blues in JAMH. See Rashida Braggs, "Evoking Baldwin's Blues: The Experience of Dislocated Listening," James Baldwin Review, 1 (2015), pp. 152-63.

36 Lee Edelman reads this scene as illustrating a confrontation with the gospel's capacity to give "emotional strength" to the couple's erotic union that is "mutually determining and relational, effected not through a fortification of boundaries but through a willingness to allow the boundaries of their identities to be penetrated." Lee Edelman, Homographesis: Essays in Gay Literary and Cultural Theory (New York, Routledge, 1994), p. 69. 
37 In attending to the queer and diasporic quality of errant kinship in $J A M H$, I echo Nadia Ellis's analysis of Baldwin's tense collaborations with George Lamming that sees Baldwin's vision of belonging as depending on a queer poetics that reimagines diaspora as turning on instances of loss and suspension. She writes: "In retaining striking traces of the gap between here and there-between the possibilities spied on the horizon and territory currently occupied-these modes produce urgent feelings of loss, desire, and zeal that mark them, like Muñoz's utopian horizon, as queer." Nadia Ellis, Territories of the Soul: Queered Belonging in the Black Diaspora (Durham, N.C., Duke University Press, 2015), p. 4.

38 Baldwin, Conversations with James Baldwin, p. 191.

39 Glissant, Poetics of Relation, p. 211.

40 Bessie Smith, "Yellow Dog Blues," www.youtube.com/watch?v=mcrx2-vvwC4 (accessed 15 March 2016).

\section{Works Cited}

Abdur-Rahman, Aliyyah, Against the Closet: Identity, Political Longing, and Black Figuration (Durham, N.C., Duke University Press, 2012).

Baldwin, James, Another Country (New York: Vintage, 1993).

Collected Essays, ed. Toni Morrison (New York, Library of America, 1998).

Conversations with James Baldwin, ed. Fred L. Standley and Louis H. Pratt (Jackson,

MS, University of Mississippi Press, 1989).

The Cross of Redemption: Uncollected Writings, ed. Randall Kenan (New York, Pantheon, 2010).

_ Just Above My Head (New York, Random House, 1979).

Birmingham, Kevin, “'History's Ass Pocket': The Source of Baldwinian Diaspora," in Cora Kaplan and Bill Schwarz (eds.), James Baldwin: America and Beyond (Ann Arbor, MI, University of Michigan Press, 2011), pp. 141-58.

Braggs, Rashida, “Evoking Baldwin's Blues: The Experience of Dislocated Listening,” James Baldwin Review, 1 (2015), pp. 152-63.

Britton, Celia M., Edouard Glissant and Postcolonial Theory: Strategies of Language and Resistance (Charlottesville, VA, University of Virginia Press, 1999).

Clark, Keith, Black Manhood in James Baldwin, Ernest J. Gaines, and August Wilson (Champaign-Urbana, IL, University of Illinois Press, 2004).

Corber, Robert J., Homosexuality in Cold War America: Resistance and the Crisis of Masculinity (Durham, N.C., Duke University Press, 1997).

Edelman, Lee, Homographesis: Essays in Gay Literary and Cultural Theory (New York, Routledge, 1994).

Ellis, Nadia, Territories of the Soul: Queered Belonging in the Black Diaspora (Durham, N.C., Duke University Press, 2015).

Glissant, Édouard, Poetics of Relation, trans. Betsy Wing (Ann Arbor, MI, University of Michigan Press, 1997).

Kaplan, Cora, and Bill Schwarz, "Introduction," in Cora Kaplan and Bill Schwarz (eds.), James Baldwin: America and Beyond (Ann Arbor, MI, University of Michigan Press, 2011), pp. 1-34.

Leeming, David, James Baldwin: A Biography (New York, Random House, 1994).

Miller, D. Quentin, "Using the Blues: James Baldwin and Music," in Douglas Field 
(ed.), A Historical Guide to James Baldwin (Oxford, Oxford University Press, 2009), pp. 83-110.

Morrison, Toni, “James Baldwin: His Voice Remembered; Life in His Language," The New York Times, 20 December 1987.

"The Noble Lecture in Literature," in What Moves at the Margin: Selected Nonfiction, ed. Carolyn C. Denard (Jackson, MS, University of Mississippi Press, 2008), pp. 198-207.

Moten, Fred, In the Break: The Aesthetics of the Black Radical Tradition (Minneapolis, MN, University of Minnesota Press, 2003).

Pavlić, Ed, Who Can Afford to Improvise? James Baldwin and Black Music, the Lyric and the Listeners (New York, Fordham University Press, 2015).

Reid-Pharr, Robert, Once You Go Black: Choice, Desire and the Black American Intellectual (New York, New York University Press, 2007).

Romano, John, "Just Above My Head," The New York Times, 23 September 1979, www. nytimes.com/books/98/03/29/specials/baldwin-above.html (accessed 10 January 2016).

Said, Edward, Beginnings: Intention and Method (New York, Columbia University Press, 1975).

Spillers, Hortense, Black, White and In Color: Essays on American Literature and Culture (Chicago, University of Chicago Press, 2003).

\section{Contributor's Biography}

Jenny M. James is an assistant professor of English at Pacific Lutheran University in Tacoma, WA, where she teaches courses on contemporary American literature and critical race, gender, and sexuality studies. She has published previously in Studies in American Fiction and MELUS: Multi-ethnic Literature of the U.S. and is currently working on a booklength study of debt, artistic collaboration, and interracial, queer kinship in mid-century American literature. 